\title{
Chromosome 7 Abnormality
}

National Cancer Institute

\section{Source}

National Cancer Institute. Chromosome 7 Abnormality. NCI Thesaurus. Code C159455.

A cytogenic abnormality that refers to any structural irregularity in chromosome 7. 